\title{
Marketing Structure and Opportunities of Almonds Products in Samangan and Balkh Provinces, Afghanistan
}

\author{
Ahmad Jawid ABDUL KHALIQ ${ }^{1}$ \\ Ismet BOZ ${ }^{1}$ \\ ${ }^{1}$ Ondokuz Mayıs University, Agricultural Faculty, Department of Agricultural Economics, \\ Samsun, Turkey, ismet.boz@omu.edu.tr
}

\begin{abstract}
The objective of the study was to identify the marketing structure and opportunities of almond products in the Samangan and Balkh provinces. The primary data were obtained from questionnaires conducted by face to face interviews with the 125 small scale almond producers and 42 intermediaries, and the secondary data collected from various sources. The collected data were analyzed using parametric and nonparametric statistical methods. According to the results of the study, the average age was 45.13 years for almond farmers and 41.44 years for intermediaries. The average schooling years were 5.40 years for farmers and 9.43 years for intermediaries. While most of the farmers were elementary school graduates, the majority of the intermediaries were secondary school graduates. The strongest aspects of the almond marketing sector in the region are the experience of the farmers and their high interest in this product. The most important opportunities are the good experience of farmers, the adaptation of almonds in Balkh and Samangan, the interest of the farmer in horticulture, availability of substantial varieties of almonds, exports competitiveness of almond products of the region, and the favorable climatic conditions. The study concludes that the government and NGOs should support producers and intermediaries in developing the infrastructure of local markets. They should provide farmers with agricultural inputs at affordable prices, implement capacity building programs, inform all stakeholders on input and product prices, develop credit opportunities, and support farmers' organizations.
\end{abstract}

Key Words: Marketing Structure, Agricultural marketing, Almond producers, intermediaries

\section{INTRODUCTION}

Afghanistan has a unique climate that provides perfect agro-climatic and bio-diversity, which is ideal for growing a variety of agricultural crops, which includes a large number of horticulture crops, especially almond. Horticulture in Afghanistan has gained its credibility for providing sustainable income, food security, and providing employment opportunities, both in rural and urban areas. Almond is one of the broadest cultivation fruit crops of the 
world in varying climatic zones extending from the temperate to the tropics in the Samangan and Balkh region of Northern Afghanistan (Khaliq and Boz, 2019). Currently, the Ministry of Agriculture, irrigation, and livestock have 78 native varieties of almonds in their germplasm sites (MAIL, 2016). Samadi reported, there are an estimated 68 to 99 Almond genotypes found in Afghanistan (Samadi, 2010). These would include the locally named varieties. There is variation between the spelling of the Almond varieties, depending on the language and the region of individuals (Driver et al. 2010). Afghanistan almonds are an important category among dried fruits and nuts products, in addition, to represent an important share of the export market of dried fruits and nuts, with the largest quantities being consumed in the domestic market (Kuhn \& Hamidzada, 2010). Afghanistan is one of the top ten producing countries in the world, but it is not well recognized internationally because of low export values. Several price calculations have shown that almonds can be price competitive in existing and new export destinations. The observation of the Indian market showed that Afghan almonds held a minimal share, a very competitive price, and the potential for the significant growth of exports (Corky \& Mark, 2010). The European market appears to be another lucrative market, where domestic almonds can be price competitive, with high per capita consumption and revenue generated from sales of this product. However, the specificities of each market must be carefully estimated and taken into consideration. In the case of the European market, Afghan almond companies have to do their homework to overcome non-tariff barriers in the form of market access requirements such as food safety, monitoring, pesticide residues, and regulations on packaging (Ferris et al., 2014). The Chinese market is another unexplored opportunity that should be strategically investigated to gain access. It is possible that personal efforts are made to move from traditional export markets to other export opportunities in the region or abroad (Neumann, 2004). The opportunities for expanding the domestic market for almonds are limited by the economic and political status of Afghanistan. The market is not only limited by the purchasing power of the consumer, but also by the geopolitical situation in the country, which limits the distribution of the product throughout the country (Lothore \& Delmas, 2009). In order, Afghan Almonds to maintain a differentiated position in the Indian market, players in the Afghan almond industry must work to improve the quality and maintain the quantity of almonds entering the Indian market (Corky \& Mark, 2010).

\section{MATERIAL AND METHODS}

\subsection{Population and sampling}

Year 5/ 2021, Volume-5, Issue-2 | WWW.ispecjournal.org 
This research was applied to identify the marketing structure and opportunities of almonds products in the Samangan and Balkh provinces of Afghanistan, as shown in Figure 1. The primary data of this research were obtained from questionnaires conducted by face to face interviews, and the secondary data of study collected from various sources (CSO, FAO reports, government publications, USAID reports, NGOs reports, journals, and websites). The target population to which the results of this study generally apply is all almond smallholder farmers and intermediaries operated in two provinces. Initially, the intermediaries and smallholder almond producers' lists and the sizes of their almond orchards were obtained from the Almond Orchard Association, Nursery Association, and Dried Fruit Seller Association. The lists covered the 2018 data and made the accessible population of this study. Using the size of almond orchards operated by each farmer as the sample size determination criterion, the accessible population was divided in three strata as small, medium, and large farmers. Then using Yamane's (2001) stratified sample size determination formula with 0.05 mean error and 95\% confidence interval, a stratified sample of 125 smallholder almond producers and 42 intermediaries were determined. This number was proportionally divided into three strata, and respondents from each stratum were randomly selected. Each respondent had an equal and independent chance of being included in the sample. The sample size determination formula was used as in Eq. 2.1.

$$
n=\frac{N \sum N_{h} S_{h}^{2}}{N^{2} D^{2}+\sum N_{h} S_{h}^{2}}, D^{2}=\frac{e^{2}}{t^{2}}
$$

Where:

$\mathrm{n}=$ Sample size of almonds farmers.

$\mathrm{N}=$ Population of almonds farmers in the main strata

$\mathrm{Nh}=$ Number of almonds farmers in each stratum

$\mathrm{Sh}=$ Standard deviation in each stratum

D2= Expected variance

$\mathrm{e}=$ Accepted error from mean

$\mathrm{t}=$ value of corresponding the accepted confidence interval

This method of sample size determination was similarly used in earlier work of Kılıç (1997), Kilıç et al. (2006), and Boz et al. (2011). 


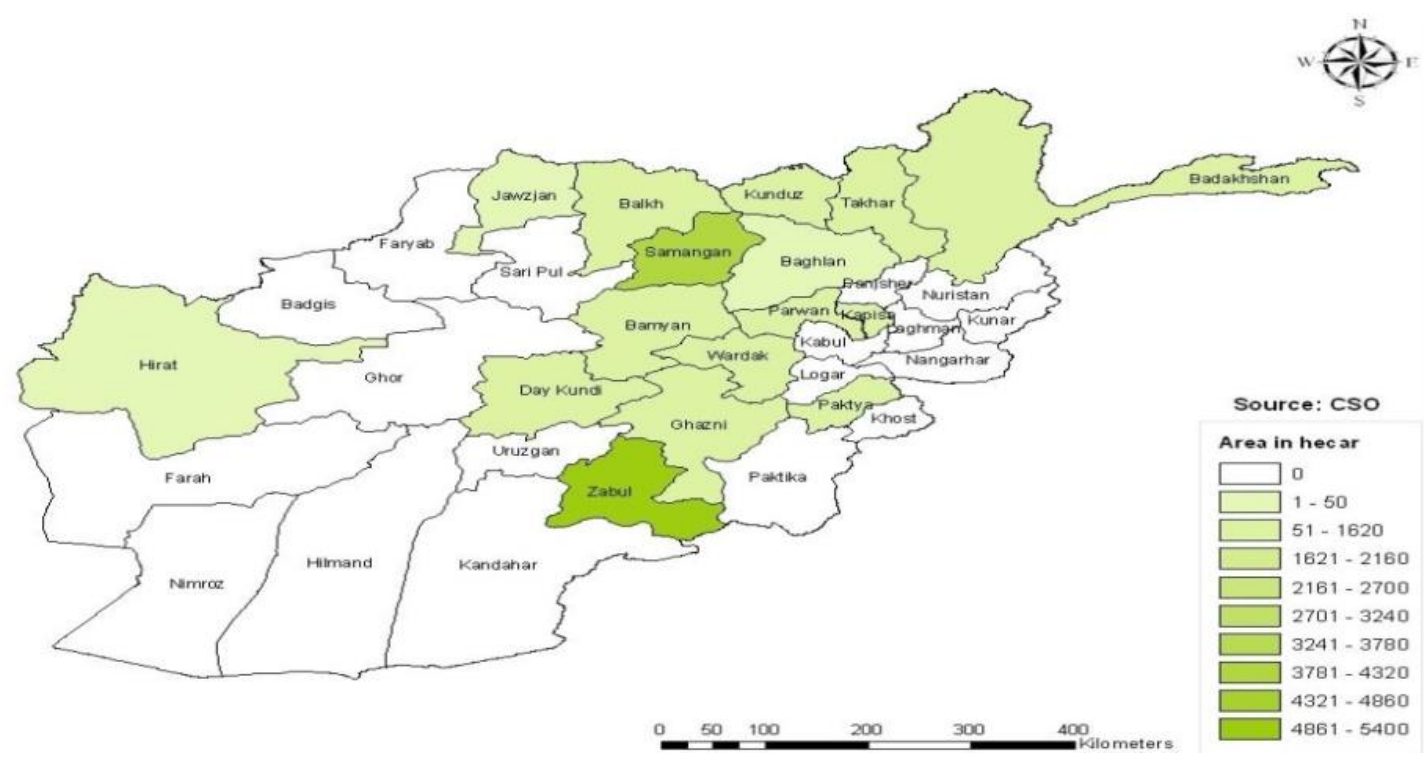

Figure 1. Map of Afghanistan, Almonds production by provinces, 2008.

\subsection{Data collection}

The data collection instrument of this study was developed using an extensive review of the related literature as well as socioeconomic characteristics and agricultural infrastructure of the region. Particularly the studies by Khaliq and Boz, 2019; ul Haq, 2019; Muradi and Boz, 2018; Yousufi, 2016; and Tatlidil et al., 2009, were explicitly utilized in preparing the questionnaire of this study. It was included questions about socio-demographic and socioeconomic characteristics of farmers, including their province, age, farm size/hectare, employment, major sources of income, annual producer income (Afghani), the status of land tenure of producers, access to market services of producers, and almond marketing services of intermediaries. In addition, questions related to almond cultivation and productivity were also included in the questionnaire. Technically the questions were both open-ended and closedended. Validity for the data collection instrument was assessed using a panel of Error! Reference source not found.experts, including the researchers and experts from the Almond Orchard Association, Nursery Association, and Dried Fruit Seller Association. Reliability was established by using a pre-test at the end of which slight changes were made in the questions which were misunderstood by the respondents. Data were collected in November 2018, and it took approximately half an hour to complete one questionnaire.

\subsection{Data analyses}

Descriptive statistics, including frequencies, percentages, means, and standard deviations, were used to analyze sociodemographic and socioeconomic characteristics of farmers and intermediaries. The remaining analyses were based on the following statistical procedures:

Year 5/ 2021, Volume-5, Issue-2 | WWW.ispecjournal.org 
One Way Analysis of Variance (ANOVA-F test): In these statistics, if the dependent variable has two or more categories, the differences among these categories in terms of the explanatory variables are determined. The ANOVA procedure was used, as shown in Eq. 2.2. (Muradi, and Akbay, 2018):

$$
\mathrm{F}=\frac{\text { MST }}{\text { MSE }}
$$

Where,

$\mathrm{F}=$ Anova Coefficient

MST $=$ Mean sum of squares due to treatment

MSE $=$ Mean sum of squares due to error.

Descriptive statistics, including means, frequency, and percentages approach, model the relationship between a dependent variable and one or more independent variables. For the opportunity evaluation, an interpretive scale was developed with the means $1.00-1.49=$ No importance (NI), 1.50-2.49 = Low importance (LI), 2.50-3.49 = Moderate importance (MI), 3.50-4.49 = High importance $(\mathrm{HI})$, and 4.50-5.00 = Very high importance (VHI) (Tatlidil \& Boz, 2009).

\section{RESULTS AND DISCUSSION}

\subsection{Production almonds in Afghanistan}

The present production of almonds in foreign countries is fully as large as it was a few years ago, and since their production is much greater than their consumption, the surplus must be sold to other countries. Almond production, which is concentrated mainly in the SouthWestern and northern regions of Afghanistan have the maximum area under cultivation. Figure 2 shows the volumes of almonds production planting area by provinces in 2017-18. The almonds production and cultivation area concentrated domestically in the South- Western and Northern Region. The Zabul province takes the first order as it is accounted for 7,000 metric tons product and 4,760 hectares planted area. Samangan is the second large producer with 6,750 metric tons and 4,500 hectares planted area. The remaining provinces with their almonds production and planted areas include the following: Balkh 3,040 metric tons, 2,027 hectares; Urozgan 3,000 metric tons, 2000 hectare; Daykundy 1,799 metric tons, 1,799 hectares; Ghazni 1,310 metric tons, 1,024 hectares; Parwan 1,100 metric tons, 1,173 hectares, Badakhshan 566 metric tons, 283 hectares, and others 2,726 metric tons, 2,227 hectares. The 
total production of almonds was 27,291 metric tons realized in 19,793 hectares planted orchard.

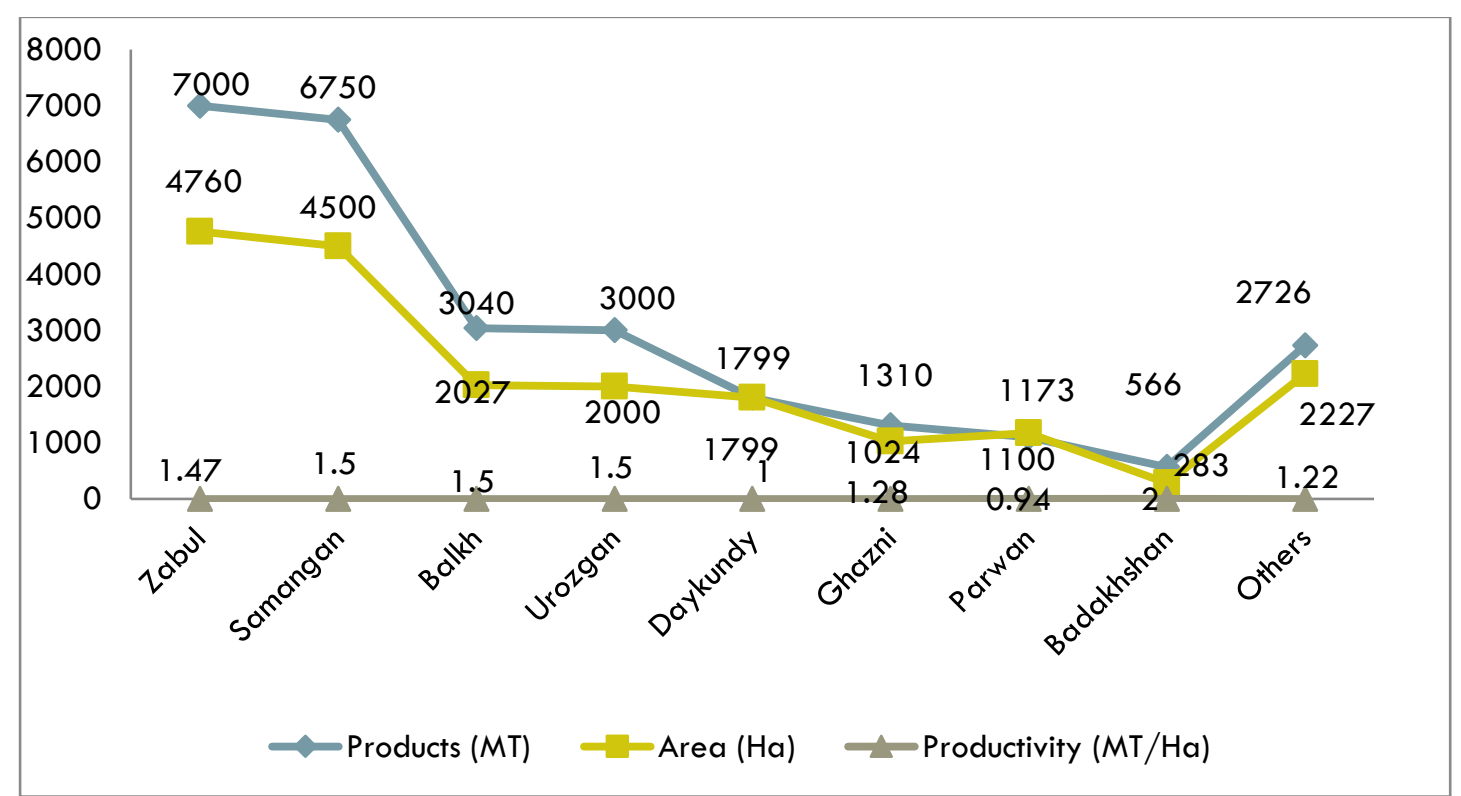

Figure 2. Almonds production and area by the provinces in 2017-18

Source: Afghanistan Statistic Organization Yearbooks, 2018

\subsection{Socio-demographic and economic characteristics}

This session includes the findings of the study and discussions, which are socio-economic characteristics such as provinces, age, farm size, employment, major sources of income, and annual producer income (Afghani). The cross-sectional study was conducted on 125 almond producers, and 42 market intermediaries in Samangan (Aybak, Hazrat-e-Sultan, and Feroz Nakhchir districts) and Balkh (Mazar-e-Sharif, Balkh, Dahdadi, Khulum, and Dewlat Abad districts) provinces, which are located in the northern region of Afghanistan. Each district of these two provinces includes many villages. As a result, $67.2 \%$ of producers and $61.9 \%$ of intermediaries were selected in Samangan, and $32.8 \%$ of producers and $38.1 \%$ of intermediaries were from Balkh province.

In the country like Afghanistan, where the family structure is very strong and based on strong family relationships, respects, values and community norms behaviour; the household head is always the decision-maker of the family; therefore, age is very important social variable because as people get older they learn different things and try to survive in their hometown and making better household and socio-economic decisions (AFSC, 2014). Age is a significant factor that affects many personality traits of the producers. The age group of farmers mainly divided into three groups; young ( $\leq 35)$, medium (36-50), and old ( $\geq 51$ ) years. 
The percentage of the first age group producers is $26.4 \%$, the second age group $41.6 \%$, and the third age group $32.0 \%$. The average age of the producers, who participated in the survey, was 45.13 years old. Also, the intermediaries were divided into the same three age groups whose percentages were $31 \%, 50 \%, 19 \%$, respectively. The average ages of intermediaries were 41.44 years old. According to the results, people of all age groups were engaged in agricultural activities and continued from father to son (family farming), and it continues. Similarly, a study about the analysis of wheat value chain: the case of Sinana district, Ethiopia, the average age of farmers was found to be 46.2 years old (Usman, 2016).

Education plays a vital role by influencing producers and intermediaries in their approach and attitude towards agricultural activities. The distribution of education levels of sample producers and intermediaries were classified into six categories based on educational status such as illiterate (no schooling), Islamic school, primary school, secondary school, high secondary school, higher education (university). The results indicate that $36.0 \%$ of producers were illiterate, $12.8 \%$ attended Islamic school, $20.0 \%$ held a primary school degree, and $10.4 \%$ continued their education to receive a secondary school degree. Those who graduated from high school were $8.0 \%$, while $12.8 \%$ graduated from university. It can be observed that the percentage of illiterates was higher than the other levels indicating that the country suffers from offering necessary educational opportunities for its citizens. The average schooling year for the farmer participants of this study was calculated as 5.40 years. The study areas have a large workforce and large land for agriculture, but there is a lack of technology and education. Currently, many farmers are illiterate and do not know modern farming methods. It should improve the quality of higher agricultural education and develop modern farming methods through talent and skills to overcome new and complex challenges. Similarly, A study conducted in the Bijapur district of Karnataka about the value chain analysis of raisin, the most level of education the farmers were illiterate (40\%), and only $13.33 \%$ were graduated from university (Nethravathi, 2012). The percentage of university graduates in the study areas was lower than the rate of university graduates in Karnataka.

The education levels of the intermediaries included the following: Illiterate (7.1\%), Islamic school (14.3\%), primary school (16.7\%), secondary school (4.6\%), high school (35.7\%), and university $(21.4 \%)$. The average schooling year for intermediaries is 9.43 years. Similarly, A study conducted in Hyderabad of India about the supply chain analysis for mangoes, the educational status of the intermediaries were as following: illiterate $(7.50 \%)$, primary school 
(10\%), secondary school (29.17\%), high school (29.17\%), and university graduates $(24.17 \%)$, respectively (Verpula, 2008). The percentage of high school in the study areas was higher than the rate of high school in Hyderabad.

It can be observed from this finding that intermediaries have a higher level of education than the farmers' community in the region. This partly represents the general farming characteristics in developing countries where farmers operate in a more traditional manner and low-level education. Since being an intermediary requires some specialized knowledge, talents, and skills, these are only possible with further education. Therefore, intermediaries in the region have a higher level of education than farmers, as shown in Table 1.

Table 1. Socio-demographic characteristics of producers and intermediaries

\begin{tabular}{|c|c|c|c|c|}
\hline \multirow{3}{*}{ Variables } & \multicolumn{2}{|l|}{ Producers } & \multicolumn{2}{|c|}{ Intermediaries } \\
\hline & Frequency & $(\%)$ & Frequency & (\%) \\
\hline & \multicolumn{2}{|l|}{$\mathrm{N}=125$} & \multicolumn{2}{|l|}{$\mathrm{N}=42$} \\
\hline \multicolumn{5}{|l|}{ Province } \\
\hline Samangan & 84 & 67.2 & 26 & 61.9 \\
\hline Balkh & 41 & 32.8 & 16 & 38.1 \\
\hline \multicolumn{5}{|l|}{ Age } \\
\hline Young $(\leq 35)$ & 33 & 26.4 & 13 & 31 \\
\hline Medium (36-50) & 52 & 41.6 & 21 & 50 \\
\hline Old $(\geq 51)$ & 40 & 32.0 & 8 & 19 \\
\hline Mean \pm SD & \multicolumn{2}{|c|}{$45.13 \pm 12.06$} & \multicolumn{2}{|l|}{$41.44 \pm 9.76$} \\
\hline \multicolumn{5}{|l|}{ Education } \\
\hline İlliterate (no schooling) & 45 & 36.0 & 3 & 7.1 \\
\hline Islamic School & 16 & 12.8 & 6 & 14.3 \\
\hline Primary school & 25 & 20.0 & 7 & 16.7 \\
\hline Secondary school & 13 & 10.4 & 2 & 4.8 \\
\hline High school & 10 & 8.0 & 15 & 35.7 \\
\hline University & 16 & 12.8 & 9 & 21.4 \\
\hline Mean \pm SD & \multicolumn{2}{|l|}{$5.40 \pm 5.61$} & \multicolumn{2}{|l|}{$9.43 \pm 5.34$} \\
\hline
\end{tabular}

Land ownership in Afghanistan is highly diversified but characterized by the fragmentation and outbreak of small scale farms and subsistence agriculture. Therefore, the details of the land size of farmers were analyzed. The results showed that the land size was classified into three groups; small farm $(<0.25)$, medium farm $(0.25 \leq \mathrm{Ha} \geq 1.00)$, and large farm $(>1.00)$. The results indicate that $30.4 \%$ of farmers have less than 0.25 hectares. This consisted of the first group of the respondents regarding their farm size. The medium farm group made $46.4 \%$ 
of total farmers, and they had a land of $0.25 \leq \mathrm{Ha} \geq 1.00$ hectares. The third group was accounted for as large farms, which made $23.2 \%$ of the total farmers having above 1.00 hectares of agricultural land. The average farm size in the locality was calculated as 0.98 hectares of land ( $\mathrm{SD}=0.78)$, as shown in Table 2. A study conducted about the value chain analysis of vegetables in Oromia of Ethiopia, the average land size of farmers, was 3.5 hectares (Hailu, 2016).

The producers were classified into three groups based on their employment status, agriculture alone, and those with farming and other occupation. The majority of respondents are farmers (92.8\%), and they are busy with agriculture and horticulture activities. Moreover, $5.6 \%$ of farmers indicated that their work is in the government sector; $1.6 \%$ of farmers are dealing with other industries. Similarly, a study on dairy cattle production, structure, and marketing opportunities in Konya province, the majority of respondents were farmers $82.6 \%$ (Muradi \& Akbay, 2018), and the percentage of farmers in the study areas was higher than the rate of farmers in Konya province.

Income is the most important factor for producers to continue their agricultural production process, and purchase the necessary consumption goods which are not produced on the farm. If the farmers have a sustainable income, it is much easier for them and their families to improve their living conditions and enjoy staying in rural areas. Otherwise, they will not prepare a good future for their children. However, in a country such as Afghanistan, only a small percentage of household members have a job in the governmental sectors due to a lack of job opportunities. Thus, most people rely on agriculture or livestock. Hence, the details of annual income were analyzed. The results are mainly classified into three groups; (low = $<300,000)$, $($ medium $=300,000-700,000)$, and (high $=>700,000)$ Afghani. The percentage of the first group was calculated as $34.4 \%$, the second group $42.4 \%$, and the third group $23.2 \%$. The average annual income of farmers in the survey was 542,782.4 Afghani.

Sustainable income and its source are essential for the producers. The income earned from the sale of agricultural products is of particular importance to the rural farmers. The cash earned from producing, collecting, selling, or processing agricultural products provides important input to family income, which enables them to purchase household equipment and invest in future agriculture production. Therefore, the producers were asked to report the four primary income sources, such as horticulture, sale of field crops, livestock, and other sources. The major sources of income for farmers were the sale of horticulture products $(68.8 \%)$, the sale 
of cereal crops (17.6\%), the sale of livestock products (6.4\%), and earnings from other sources $(7.2 \%)$. It revealed that the horticulture plays a significant role in producers' lifestyle. Thus, this was to imply that the main income source of producers was the sale of horticulture products, as there is enormous potential in high income from horticulture productions in the study areas, as shown in Table 2.

Table 2. Socio-economic characteristics of almond producers

\begin{tabular}{|c|c|c|c|c|c|}
\hline Variables & Fre. & $(\%)$ & Variables & Fre. & $(\%)$ \\
\hline \multicolumn{3}{|l|}{ Farm Size/Hectare } & \multicolumn{3}{|l|}{ Employment } \\
\hline Small farm $(<0.25)$ & 38 & 30.4 & Farmer & 116 & 92.8 \\
\hline $\begin{array}{l}\text { Medium farm }(0.25 \leq \mathrm{Ha} \geq \\
1.00)\end{array}$ & 58 & 46.4 & $\begin{array}{l}\text { Gov. sector permanent } \\
\text { worker }\end{array}$ & 7 & 5.6 \\
\hline Large farm $(>1.00)$ & 29 & 23.2 & Others & 2 & 1.6 \\
\hline Mean \pm SD & \multicolumn{2}{|c|}{$0.98 \pm 0.78$} & \multirow{2}{*}{$\begin{array}{l}\text { Major sources of income } \\
\text { Sale of horticulture products }\end{array}$} & & \\
\hline \multicolumn{3}{|c|}{ Annual producer income (Afghani) } & & 86 & 68.8 \\
\hline Low income $(<300,000)$ & 43 & 34.4 & Sale of cereal crops & 22 & 17.6 \\
\hline $\begin{array}{l}\text { Medium income }(300,000 \\
700,000)\end{array}$ & 53 & 42.4 & Sale of livestock & 8 & 6.4 \\
\hline High income $(>700,001)$ & 29 & 23.2 & \multirow[t]{2}{*}{ Others } & 9 & 7.2 \\
\hline Mean \pm SD $\quad 542,782.4$ & \pm 493 & & & & \\
\hline
\end{tabular}

\subsection{Status of land tenure of producers}

Agricultural land tenure refers to the package of rights and responsibilities that are owned, rented, shared, rented out, and shared out arable land under permanent agriculture crops. Land tenure is an agreement and relationship, whether defined legally or customarily, among the people as individuals or groups, concerning land. Land tenure is an important element of economic, social, and political structures. It is multi-dimensional and involves economic, social, technical, and political aspects that are frequently ignored but need to be taken into account (Studies, 2002). In Afghanistan, agricultural land is utilized under different tenure forms; first, farmers operating their land. Second, farmers do not have their own land but operate lands belongs to other individuals or the government. The landholding and utilizing only on a shared basis is also dominant in the country in a small proportion. On the other hand, this operating system also bears the costs and also contributes to the country's economy. Table 4.3 shows the land holdings and type tenure forms in the study area. The average agricultural owned land is 1.50 hectares, rented land 0.57 , shared land 0.19 , rented out 0.29 , shared out 0.04 , and the average area allocated to almond is 0.98 hectares, as shown in Table 3. Similarly, a study conducted on the analysis of the wheat value chain in the Sinana district, Oromia region of Ethiopia. The average agricultural owned land was 3.91 hectares, rented in 
0.2 hectares, and rented out 0.11 hectares, shared in 0.21 hectares, and the average land allocated for wheat was 2.92 hectares, respectively. All farmers indicated that they were actively involved in wheat production (Usman, 2016).

Table 3. Status of the land of tenure (hectare)

\begin{tabular}{lllll}
\hline Variables & Minimum & Maximum & Mean & $\begin{array}{l}\text { Std. } \\
\text { Deviation }\end{array}$ \\
\hline Area of owned land & 0.10 & 10.0 & 1.50 & 1.44 \\
Area of rented land & 0.00 & 10.0 & 0.57 & 1.42 \\
Area of shared land & 0.00 & 8.4 & 0.19 & 0.81 \\
Area of rented out & 0.00 & 14.0 & 0.29 & 1.59 \\
Area of shared out & 0.00 & 1.2 & 0.04 & 0.16 \\
The area allocated for almond & 0.11 & 4.0 & 0.98 & 0.78 \\
\hline
\end{tabular}

\subsection{Access to market services of producers}

Almond marketing system is described as physical and institutional set up to perform all activities involved in the flow of products and services from the point of initial production until they are in the hands of ultimate customers. This includes assembling, handling, storage, transport, processing, wholesaling, retailing, and export of agricultural commodities as well as accompanying support services such as market information, commodity trade, financing and price risk management, and the institutions involved in performing the above functions. Almond marketing consists of many different actors, such as contractors/middlemen, retailers, wholesalers, processors, and exporters. Farmers sell their products via an intermediary. Table 4, showed that $38.4 \%$ of the producers sell their products to wholesalers, $28.0 \%$ to the contractors/middleman, $22.4 \%$ to retailers, $8.0 \%$ to processors, $1.6 \%$ to exporters, and $1.6 \%$ to others.

As can be seen from these figures, farmers are largely dependent on other individuals while marketing their products. Although some of them use very high quality of inputs and increase the quality and quantity of almond production, they almost have no influence on determining the selling price of almond. Moreover, they have no opportunities to further process and diversify their products for additional values. This situation put high restrictions on almond farmers to develop their business.

The market place is one of the essential elements of almond production. The market places for the selling of almond products in the locality include village markets, district markets, city markets, associations/cooperatives/unions, on orchard sales, open market sales, and own consumption. All of these markets, with their characteristics, transfer the produced almonds 
from farmers to the consumers. Table 4, shows that $53.6 \%$ of farmer sell their products to the city market, $24.0 \%$ district markets, $12.0 \%$ other markets (on the orchard, open market), $6.4 \%$ (association/cooperatives/ union and own consumption), and $4.0 \%$ to the village market.

Transportation implies a series of activities involved in moving the goods from the point of production to the point of consumption. Table 4 shows the main transportation used for almond products in the study area, that intake $74.4 \%$ of producers transporting their products by vehicle, $19.2 \%$ Rickshaw, $4.8 \%$ Cart, and $1.6 \%$ of farmers transporting their products by pack animal.

Interpersonal relationships between farmers and traders influence their trade as some farmers prefer to sell their products to their friends while other farmers prefer someone else. Table 4, shows the relationships between farmers and buyers (traders). Of the total farmers, $66.4 \%$ had no relation with buyers, $16.0 \%$ sell their products to an acquaintance, $10.4 \%$ sell their products to friends, and $7.2 \%$ sell their products to relatives.

Table 4. Market services of almond producers

\begin{tabular}{|c|c|c|c|c|c|}
\hline \multirow{2}{*}{ Variables } & Fre. & $(\%)$ & \multirow{2}{*}{ Variables } & Fre. & $(\%)$ \\
\hline & \multicolumn{2}{|c|}{$\mathrm{N}=125$} & & \multicolumn{2}{|c|}{$\mathrm{N}=125$} \\
\hline Main Buyer & \multicolumn{5}{|c|}{ Main transportation } \\
\hline Wholesaler & 48 & 38.4 & Vehicle & 93 & 74.4 \\
\hline Contractor/middleman & 35 & 28.0 & Rickshaw & 24 & 19.2 \\
\hline Retailer & 28 & 22.4 & Cart & 6 & 4.8 \\
\hline Processor & 10 & 8.0 & Pack animal & 2 & 1.6 \\
\hline Exporter & 2 & 1.6 & Total & 125 & 100 \\
\hline Others & 2 & 1.6 & \multicolumn{3}{|c|}{ Relationship between farmers and traders } \\
\hline Total & 125 & 100 & No relation & 83 & 66.4 \\
\hline Place of selling & & & Acquaintance & 20 & 16.0 \\
\hline City market & 67 & 53.6 & Friend & 13 & 10.4 \\
\hline District market & 30 & 24 & Relative & 9 & 7.2 \\
\hline Association/Cooperatives/Union & 8 & 6.4 & Total & 125 & 100 \\
\hline Village market & 5 & 4.0 & & & \\
\hline $\begin{array}{l}\text { Other (On orchard, Open market, } \\
\text { Own consumption) }\end{array}$ & 15 & 12.0 & & & \\
\hline Total & 125 & 100 & & & \\
\hline
\end{tabular}

\subsection{Almond marketing services of intermediaries}

The main changes made in almonds after purchasing from farmers include grading, packing, storage, and other processed products. The results show that $33.15 \%$ of respondents are grading, $31.43 \%$ packing, $29.72 \%$ storing, and $5.71 \%$ processing to other products. The 
average quantity of graded almonds was $2635.50 \mathrm{~kg}$, packed $3341.33 \mathrm{~kg}$, stored $8101.53 \mathrm{~kg}$, and other products $2460 \mathrm{~kg}$, as shown in Table 5 .

Table 5. Intermediaries changes after buying $(\mathrm{kg})$

\begin{tabular}{lllll}
\hline Category & Frequency & \% & Average & Std. Deviation \\
\hline Grading & 58 & 33.14 & 2635.50 & 3732.03 \\
Packing & 55 & 31.43 & 3341.33 & 4777.93 \\
Storage & 52 & 29.72 & 8101.53 & 9969.81 \\
Other & 10 & 5.71 & 2460.00 & 2898.28 \\
Total & 175 & 100.00 & 4477.97 & 6869.89 \\
\hline
\end{tabular}

In order to function regularly and continue their business, intermediaries need to purchase enough almonds to forward in the following steps of the marketing process. The major suppliers of almond for intermediaries in the study area have been analyzed. Table 6 shows that $80.58 \%$ of almonds are provided by farmers, $8 \%$ local trader, $5.71 \%$ contractor/middleman, $5.71 \%$ wholesalers. Also, the average quantity of almond provided by farmers was $3009.64 \mathrm{~kg}$, local trader $7525.00 \mathrm{~kg}$, contractor/middleman $7450 \mathrm{~kg}$, and wholesalers $18040 \mathrm{~kg}$, respectively.

Table 6. Major suppliers of almond for intermediaries

\begin{tabular}{lllll}
\hline Variables & Frequency & $\%$ & Average & $\begin{array}{l}\text { Std. } \\
\text { Deviation }\end{array}$ \\
\hline Farmers & 141 & 80.58 & 3009.64 & 4049.40 \\
Local trader & 14 & 8.00 & 7525.00 & 6911.164 \\
Contractor/middleman & 10 & 5.71 & 7450.00 & 6882.475 \\
Wholesalers & 10 & 5.71 & 18040.00 & 16247.51 \\
Total & 175 & 100.00 & 4477.97 & 6869.89 \\
\hline
\end{tabular}

The main objective of all intermediaries is to attract customers and make them purchase their products. The result of Table 7 shows that the major of almond customers are $26.19 \%$ of retailers, $23.81 \%$ exporter, $19.05 \%$ consumers, $16.66 \%$ wholesalers, and $14.29 \%$ contractor/middleman. Moreover, the average quantity purchasing by retailers is $3682.66 \mathrm{~kg}$, exporter $9987.12 \mathrm{~kg}$, consumers $5238.09 \mathrm{~kg}$, wholesalers $1689.13 \mathrm{~kg}$, contractor/middleman $1025.94 \mathrm{~kg}$, respectively. 
Table 7. Major customers of almonds

\begin{tabular}{lllll}
\hline Variables & Frequency & $\%$ & Average & Std. Deviation \\
\hline Retailers & 11 & 26.19 & 3682.66 & 7102.75 \\
Exporter & 10 & 23.81 & 9987.12 & 9736.46 \\
Consumers & 8 & 19.05 & 5238.09 & 6220.42 \\
Wholesalers & 7 & 16.66 & 1689.13 & 1251.29 \\
Contractor/middleman & 6 & 14.29 & 1025.94 & 1204.27 \\
Total & 42 & 100.00 & 4613.03 & 7155.69
\end{tabular}

Place of selling for intermediaries is one of the essential elements of the almond marketing. The markets for the selling of almond products by intermediaries are the district markets, city markets, and other markets (own consumption, village market, and open market). Table 8 shows that $57.14 \%$ of traders sell their almonds to the city markets, $28.57 \%$ district markets, and $14.29 \%$ other markets (own consumption, village market, and open market). Additionally, the average quantity sold to the city market was $3024.82 \mathrm{~kg}$, district market $2856.00 \mathrm{~kg}$, and other markets $5595.33 \mathrm{~kg}$, respectively.

Table 8. Place of selling almond

\begin{tabular}{lllll}
\hline Variables & Frequency & \% & Average & Std. Deviation \\
\hline City market & 24 & 57.14 & 3024.82 & 4693.08 \\
District market & 12 & 28.57 & 2856.00 & 3364.88 \\
Others (Own consumption, Village market, & 6 & 14.29 & 5595.33 & 8194.88 \\
Open market) & 42 & 100.00 & 4627.87 & 7166.92 \\
Total & 42 & &
\end{tabular}

Exports play a vital role in the development of the agricultural sector, particularly in developing countries. Most of the agricultural products are sold at higher prices in international markets compared with domestic markets. If marketing margins are low and the majority of prices paid by consumers go to farmers, their income and wellbeing will probably increase. The higher income of farmers will make significant contributions to sustainable agriculture in developing countries. Therefore, encouraging and even supporting the exports of farm commodities will have profound influences on agricultural production and marketing. The results of the study showed that $52.4 \%$ of intermediaries export almonds outside the country, and $47.6 \%$ of intermediaries vice versa. The average almond exported by intermediaries was $45850 \mathrm{~kg}$, as shown in Table 9.

This result indicates that almost half of the intermediaries involved in almonds marketing in the research area have no international connections and limited to domestic marketing 
opportunities. Therefore, to make more contributions to the local economy, more intermediaries should try to find relationships with global markets.

Table 9. Intermediaries: Export to other countries

\begin{tabular}{llll}
\hline Variables & Frequency & $\%$ & $\begin{array}{l}\text { Average } \\
(\mathbf{k g})\end{array}$ \\
\hline Yes & 22 & 52.4 & \\
No & 20 & 47.6 & 45850 \\
Total & 42 & 100 & \\
\hline Accoring to
\end{tabular}

According to the study, intermediaries have to sell their products on credit. The results show that $78.6 \%$ of intermediaries selling their products on credit, and $21.4 \%$ not selling their products on credit. The average months waiting for payment was 3.71 months had been founded, as shown in Table 10.

Table 10. Selling on credit

\begin{tabular}{llllll}
\hline Variables & Frequency & $\%$ & \multicolumn{3}{l}{ Months waiting for payment } \\
\hline Yes & 33 & 78.6 & Average & Minimum & Maximum \\
No & 9 & 21.4 & 3.71 & 1 & 12 \\
Total & 42 & 100 & & 1 & \\
\hline
\end{tabular}

Transportation implies a series of activities involved in moving the goods from the point of production to the point of consumption. Table 11 shows the main transportation used for almond products in the study area, that intake 59.5\% transporting their products by vehicle, $28.6 \%$ Rickshaw, and $11.9 \%$ other transportation.

Table 11. Transportation of traders

\begin{tabular}{lll}
\hline Variables & Frequency & \% \\
\hline Vehicle & 25 & 59.5 \\
Rickshaw & 12 & 28.6 \\
Others & 5 & 11.9 \\
Total & 42 & 100 \\
\hline
\end{tabular}

Total almond production, the quantity of almonds sold, almonds price, and marketing cost by the variety of almonds were analyzed in Table 12. According to results of one way ANOVA, the total average of (almond production was $475.82 \mathrm{~kg}$, quantity of almonds sold $399.44 \mathrm{~kg}$, almonds price $298.08 \mathrm{Afs} / \mathrm{kg}$, and marketing cost 445.60 Afghani), it is statistically significant difference in the average of almond production, quantity of almonds sold, almonds price, and marketing costs. 
Table 12. Average almonds production, quantity of almonds sold, almonds price and marketing cost by almond varieties

\begin{tabular}{|c|c|c|c|c|}
\hline Varieties & Production (kg) & $\begin{array}{l}\text { Quantity } \\
\text { almonds sold (kg) }\end{array}$ & $\begin{array}{l}\text { ofAlmonds } \\
\text { Afs } / \mathrm{kg}\end{array}$ & $\begin{array}{r}\text { priceMarketing } \\
\text { costs (Afs) }\end{array}$ \\
\hline Satar Bayee & 373.06 & 361.04 & 519.40 & 358.80 \\
\hline Shokar Bayee & 579.35 & 485.26 & 255.88 & 562.49 \\
\hline Qambari (Ghambari) & 402.89 & 331.25 & 309.00 & 384.00 \\
\hline Khairuddini (Khairuldini) & 534.96 & 386.40 & 257.31 & 528.71 \\
\hline Qahar Bayee & 481.00 & 402.00 & 299.86 & 466.00 \\
\hline Murawaji (Moravaja) & 626.18 & 498.26 & 165.60 & 579.60 \\
\hline Qari bayee & 402.82 & 470.91 & 263.27 & 402.36 \\
\hline Abdul Wahedi & 620.00 & 516.00 & 283.71 & 542.14 \\
\hline Majidi & 198.33 & 171.89 & 193.78 & 195.56 \\
\hline Sangak (Sanghak) & 358.93 & 293.03 & 106.66 & 215.83 \\
\hline Kaghazi (Khaghazi) & 383.00 & 308.00 & 293.00 & 383.00 \\
\hline Others & 229.25 & 167.13 & 346.50 & 110.50 \\
\hline Average & 475.82 & 399.44 & 298.08 & 445.60 \\
\hline F-test (P-value) & $2.538(0.004)$ & $1.913(0.036)$ & $296.845(0.000)$ & $2.974(0.001)$ \\
\hline
\end{tabular}

Afghanistan has much potential and many opportunities to rise once again, and produce good quality almond products, not only for domestic use but also for export to neighbors and more distant countries. This will help Afghanistan take steps toward sustainable horticulture and the development of a viable economy. In order to make a clear picture of the activities, the opportunities may promote or give insight to the almond producers. The internal and external environment involved six major opportunities that were placed by the respondents in the highimportance (HI) category. These were the good experience of farmers, a good adaptation of almonds in Balkh and Samangan, the interest of farmers in horticulture, the suitability of the climate for growing almonds, availability of large almonds varieties, and competitiveness of almond products of Afghanistan in export markets. There were 12 items in the mediumimportance (MI) category. These were the existence of the domestic market, there is no labor shortage and labor fees are relatively cheap, almond have positive effects on heart and cardiac vascular diseases, almond can be produced economically under irrigated conditions, almond fruits' market is one of the fastest growing markets, almond production in every region of Afghanistan is possible except the South and the West region, Afghanistan's convenient location to those potential buyer countries such as Asian countries and European countries, 
marketing services of almonds, existence of NGOs, existence of local institution, mobilization of almond producer associations and cooperatives, and mobilize of the farmers under the almond association and cooperatives. No practice was rated to be of very high importance (VHI), low importance (LI), and no importance

Table 13. Opportunities evaluation for almond producers

\begin{tabular}{|c|c|c|c|c|}
\hline Rank & Opportunities & Mean & SD & Category \\
\hline 1 & Good experience of farmers & 4.24 & 1.011 & $\mathrm{HI}$ \\
\hline 2 & Adaptation of almond in Balkh and Samangan & 4.09 & .933 & $\mathrm{HI}$ \\
\hline 3 & The interest of the farmers to horticulture & 4.00 & .959 & $\mathrm{HI}$ \\
\hline 4 & Climate is suitable for growing almond in this province & 3.87 & .992 & $\mathrm{HI}$ \\
\hline 5 & Large varieties of almonds available & 3.86 & 1.003 & $\mathrm{HI}$ \\
\hline 6 & Almond products are competitive export for Afghanistan & 3.57 & 1.003 & $\mathrm{HI}$ \\
\hline 7 & Existence of domestic market & 3.48 & .964 & MI \\
\hline 8 & There is no labor shortage labor fees are relatively cheap & 3.37 & .972 & MI \\
\hline 9 & $\begin{array}{l}\text { Almonds have positive effects on the heart and cardiac vascular } \\
\text { diseases }\end{array}$ & 3.34 & .976 & MI \\
\hline 10 & Almond can be produced economically under irrigated conditions & 3.27 & .954 & MI \\
\hline 11 & Almond fruits' market is one of the fastest-growing markets & 3.21 & .816 & MI \\
\hline 12 & $\begin{array}{l}\text { Almond production in every region of Afghanistan is possible } \\
\text { except the South and West region }\end{array}$ & 3.20 & 1.063 & MI \\
\hline 13 & $\begin{array}{l}\text { Afghanistan's convenient location to those potential buyer countries } \\
\text { such as Asian countries and European countries }\end{array}$ & 3.15 & .968 & MI \\
\hline 14 & Marketing service of almonds & 3.14 & .953 & MI \\
\hline 15 & Existence of NOGs & 3.06 & 1.095 & MI \\
\hline 16 & Existence of local institution & 2.93 & 1.064 & MI \\
\hline 17 & Mobilization of Almond producer associations and cooperatives & 2.75 & 1.112 & MI \\
\hline 18 & $\begin{array}{l}\text { Mobilize of the farmers under the almond association and } \\
\text { cooperatives }\end{array}$ & 2.70 & 1.115 & MI \\
\hline \multicolumn{2}{|r|}{ Overall index } & 61.23 & 17.95 & \\
\hline
\end{tabular}

(NI), as shown in Table 13.

\section{CONCLUSIONS AND RECOMMENDATION}

Almonds are a significant category among the dried fruits and nuts products in Afghanistan. Production and exports have increased dynamically for ten years. Dried fruits and nuts have a considerable share in the export market and consumed in the most significant quantities in the domestic market. The large exporter of almonds and has considerable potential to increase 
exports, particularly to Pakistan, India, and small importers in the Middle East, including Iran, UAE, Turkey, Iraq, and Saudi Arabia. In the case of the European market, Afghan companies need to do their homework to comply with non-tariff barriers in the form of market access requirements such as food safety, tracing, pesticide residue levels, and packaging regulation. The Chinese market is another unexplored opportunity that should be strategically investigated to gain access. As a result, Afghanistan's unshelled almond nuts are exporting a higher premium than the imported product, the yields are probably higher, and the percentage of meats is larger. However, the restrictions on almond cultivation present a question the general public is willing to pay at increased prices for the maintenance and development of the almond industry. Almond producers derive the least benefit from their products due to the unavailability of direct selling options on the markets by limiting the involvement of the contractors/middlemen due to the lack of access to financial resources. Therefore, innovation does not have a chance to increase the efficiency of the business. The production process has remained the same for centuries in these regions without using technology, modern machinery, and irrigation systems, and techniques to make better use of cultivation areas. Poor infrastructure in these areas, such as lack of electricity, paved roads for careless access to quality patricides, and education related to agriculture, remain the main challenge of almonds production in the study areas. The following suggestions and policy inputs have emerged to reorganize the almond marketing in the study areas.

1. Providing long-term loans without interest rate for the almond producers and investor;

2. To support small, medium and large size of almond producers and trader for consortia to export more;

3. To create a chamber of commerce and industry and industrial park in the study area;

4. Holding dry fruit exhibitions at the provincial levels;

5. Supporting farmers in order to optimize the use of pesticide;

6. Efforts to increase the capacity of small and medium entrepreneurs in the field of marketing, packaging, branding and etc;

7. To construct a large store for the preservation of almond products;

8. Support, endurance and motivation of university graduates to set up small businesses in the field of dried fruit. 


\section{REFERENCES}

AFSC. (2014). Seasonal Food Security Assessment (SFSA) Afghanistan.

Boz, I., Akbay, C., Bas, S., \& Budak, D.B. (2011). Adoption of innovations and best management practices among dairy farmers in the Eastern Mediterranean Region of Turkey. Journal of Animal and Veterinary Advances,10, 251-261

Corky, L. and Mark, B. (2010). An Almond Marketing Manual for Afghanistan, Afghanistan Needs to Develop A "Complete" Almond Marketing Plan to Maintain and Enhance their Competitiveness in the World Almond Market, No:55 Kabul, Pp48.

Driver, J., \& Corwyn E. Lovin. 2010. International Programs Office/College of Agricultural and Environmental Sciences/University of California, Davis.

FAOSAT, (2016). Food and Agricultural Organization. Almond Production in Afghanistan. $16 / 03 / 2017$.

Ferris, S., Robbins, P., Best, R., Seville, D., Buxton, A., Shriver, J., \& Wei, E. (2014). Linking smallholder farmers to markets and the implications for extension and advisory services. MEAS Brief, 4, 13-14.

Government of Afghanistan, Central Statistics Organization (CSO), (2016). Agriculture Development. Kabul: CSO.

Hailu, A. (2016). Value Chain Analysis of Vegetables: The Case of Ejere District, West Shoa Zone, Oromia National Regional State Of Ethiopia (Doctoral Dissertation, Haramaya University).

Khaliq, A. J. A., \& Boz, I. (2019). Evaluating market structures and credit services for small scale almond producers in the Samangan and Balkh Provinces, Afghanistan. Asian Journal of Agricultural Extension, Economics \& Sociology, 1-8.

Kılıç, O. (1997). Samsun ili Çarşamba ve Terme ilçelerinin ova köylerinde findık üretimine yer veren tarım işletmelerinin ekonomik analizi ve fındığa alternatif üretim planlarının araştırılması. Ankara Üniversitesi Fen Bilimleri Enstitüsü Tarım Ekonomisi Anabilim dalı doktora tezi, p:170.

Kılıç, O., Cinemre, H.A., Ceyhan, V., Bozoğlu, M., (2006). Alternative farm plan for controlling hazelnut supply in Turkey. Agricultural Economics and Rural Development, 3, 85-94.

Kuhn, G \& Hamidzada, J. (2010). Almond of Afghanistan. Afghan Almond Development Industry Organization, No:25. Afghanistan Pp38.

Year 5/ 2021, Volume-5, Issue-2 | WWW.ispecjournal.org 
Lothore, A., \& Delmas, P. (2009). Market Access and Agricultural Product Marketing: Promoting Farmer Initiatives.

MAIL. (2016). National Comprehensive Agriculture Development Priority Program, Minister of Agriculture, Irrigation and Livestock 2016 - 2021.

Muradi, A. J., \& Akbay, C. (2018). Structure and marketing opportunities on dairy farms in Konya province, Turkey. International Journal of Scientific Research and Management, 6(10). Muradi, A. J., \& Boz, I. (2018). The contribution of agriculture sector in the economy of Afghanistan. International Journal of Scientific Research and Management, 6(10).

Nethravathi, A. P. (2012). Value Chain Analysis of Raisin - A Study in Bijapur District of Karnataka (Doctoral dissertation, University of Agricultural Sciences GKVK, Bangalore).

Neumann, J. L. (2004). Farmers' markets: Connecting Citizens with Local Agriculture in British Columbia.

Samadi, G. (2010). Almond Industry Development Project Six Month Report, EC Perennial Horticultural Development Project (PHDP), European Union and Roots of Peace.

Studies, L. T. (2002). Land Tenure and Rural Development. Food and Agriculture Organization of the United Nations.

Tariq, A. (2011). An Economic Analysis Of Almond Production In Afghanistan (Doctoral dissertation, Acharya Ng Ranga Agriculture University).

Tatlıdil, F. F., Boz, İ., \& Tatlidil, H. (2009). Farmers' perception of sustainable agriculture and its determinants: a case study in Kahramanmaras province of Turkey. Environment, Development and Sustainability, 11(6), 1091-1106.

Ul Haq, S. (2019). Factors influencing shareholder farming system in tea production and its effects on sustainability in Rize province. (Doctoral dissertation, Ondokuz Mayis University) Samsun, Turkey.

Usman, S. (2016). Analysis of Wheat Value Chain: The Case of Sinana District, Bale Zone, Oromia Region, Ethiopia (Doctoral dissertation, Haramaya University).

Verpula, R. (2008). Supply Chain Analysis for Mangoes in Hyderabad (Doctoral Dissertation, Acharya Ng Ranga Agricultural University, Rajendranagar, Hyderabad).

Yamane, T. (2001). Elementary sampling methods (Turkish translation), Farmers' perception of sustainable agriculture and its determinants: a case study in Kahramanmaras province of Turkey. Environment, Development and Sustainability, 11(6), 1091-1106. 
Yousufi, A. (2016). Horticulture in Afghanistan: Challenges and opportunities. Journal of Developments in Sustainable Agriculture, 11, 36-42. 